\title{
Review \\ Medicinal Components in Edible Mushrooms on Diabetes Mellitus Treatment
}

\author{
Arpita Das ${ }^{1}$, Chiao-Ming Chen ${ }^{2} \mathbb{D}$, Shu-Chi Mu ${ }^{3,4}$, Shu-Hui Yang ${ }^{5}$, Yu-Ming Ju ${ }^{6}$ and Sing-Chung Li ${ }^{1, *(\mathbb{D})}$ \\ 1 School of Nutrition and Health Sciences, College of Nutrition, Taipei Medical University, Taipei 11031, Taiwan; \\ da07110008@tmu.edu.tw \\ 2 Department of Food Science, Nutrition and Nutraceutical Biotechnology, Shih Chien University, \\ Taipei 10462, Taiwan; charming@g2.usc.edu.tw \\ 3 Department of Pediatrics, Shin-Kong Wu Ho-Su Memorial Hospital, Taipei 11101, Taiwan; \\ musc1004@gmail.com \\ 4 School of Medicine, College of Medicine, Fu-Jen Catholic University, New Taipei City 24205, Taiwan \\ 5 Fengshan Tropical Horticultural Experiment Branch, Taiwan Agricultural Research Institute, \\ Kaohsiung City 83052, Taiwan; debbie@tari.gov.tw \\ 6 Institute of Plant and Microbial Biology, Academia Sinica, Taipei 11529, Taiwan; yumingju@gate.sinica.edu.tw \\ * Correspondence: sinchung@tmu.edu.tw; Tel.: +886-2-27361661 (ext. 6560)
}

check for updates

Citation: Das, A.; Chen, C.-M.; Mu, S.-C.; Yang, S.-H.; Ju, Y.-M.; Li, S.-C. Medicinal Components in Edible Mushrooms on Diabetes Mellitus Treatment. Pharmaceutics 2022, 14 , 436. https://doi.org/10.3390/ pharmaceutics14020436

Academic Editor: Anna Rita Bilia

Received: 20 January 2022

Accepted: 14 February 2022

Published: 17 February 2022

Publisher's Note: MDPI stays neutral with regard to jurisdictional claims in published maps and institutional affiliations.

Copyright: () 2022 by the authors Licensee MDPI, Basel, Switzerland. This article is an open access article distributed under the terms and conditions of the Creative Commons Attribution (CC BY) license (https:// creativecommons.org/licenses/by/ $4.0 /)$.

\begin{abstract}
Mushrooms belong to the family "Fungi" and became famous for their medicinal properties and easy accessibility all over the world. Because of its pharmaceutical properties, including antidiabetic, anti-inflammatory, anti-cancer, and antioxidant properties, it became a hot topic among scientists. However, depending on species and varieties, most of the medicinal properties became indistinct. With this interest, an attempt has been made to scrutinize the role of edible mushrooms (EM) in diabetes mellitus treatment. A systematic contemporary literature review has been carried out from all records such as Science Direct, PubMed, Embase, and Google Scholar with an aim to represents the work has performed on mushrooms focuses on diabetes, insulin resistance (IR), and preventive mechanism of IR, using different kinds of mushroom extracts. The final review represents that EM plays an important role in anticipation of insulin resistance with the help of active compounds, i.e., polysaccharide, vitamin $\mathrm{D}$, and signifies $\alpha$-glucosidase or $\alpha$-amylase preventive activities. Although most of the mechanism is not clear yet, many varieties of mushrooms' medicinal properties have not been studied properly. So, in the future, further investigation is needed on edible medicinal mushrooms to overcome the research gap to use its clinical potential to prevent non-communicable diseases.
\end{abstract}

Keywords: edible mushroom; insulin resistance; diabetes; polysaccharide; vitamin D; $\alpha$-glucosidase; $\alpha$-amylase

\section{Introduction}

The word "mushroom" is derived from the Latin and Greek words "fungus" and "mykes" and is considered edible if consumption does not cause health disorders. Based on the edibility, it can be divided into three groups-edible (Lepiota procera), inedible or poisonous (Lepiota margani), and non-poisonous [1]. For thousands of years, mushrooms have been used as food and medicine (38\%), and many Asian and south-Asian countries use traditional wild edible mushrooms as appealing and nutritious foods, including China, Japan, India, and Taiwan. As a result, mushrooms received a high demand in the global market with 34 billion $\mathrm{kg}$ production and per capita consumption of $4.7 \mathrm{~kg}$ in 2013. Some of the significant ordinarily available edible mushrooms are chanterelles (Cantharellaceae), puffballs (Lycoperdon spp. and Calvatia spp.), shaggy mane (Coprinus comatus), two oyster mushrooms (Pleurotus ostreatus and Pleurotus cystidiosus), boletes (Boletaceae), sulfer shelf (Laetiporus sulphurous), hen of the woods (Grifora frondosa), button mushroom (Agricus bisporus), golden oyster mushroom 
(Pleurotus citrinopileatus) [2-4], morels (Morachella esculenta), bearded tooth (Hericium erinaceus), straw mushroom (Volvariella volvacea) [5,6], Eenoki (Flammulina velutipes) [7], shiitake (Lentinula edodes) [8], beech mushroom (Hypsizygus marmoreus) [9], french horn mushroom (Pleurotus eryngii) [10], dancing mushroom (Grifola frondosa) [11], and black poplar mushroom (Agrocybe aegerita) [12]. Wild edible mushrooms are not only superior for the chemical and nutritional characteristics but also the protein and vitamin contents, B vitamins, vitamin D, vitamin K, and rarely vitamin A and C [13-15]. Moreover, mushrooms have low-fat content and are high in dietary fiber, nutraceuticals, and polysaccharides, which show positive health benefits on several diseases through their immunomodulatory and anti-inflammation properties $[16,17]$. The core structural polysaccharides from mushrooms include homoglucans $(\beta-1$, 3 glucan), heteroglycans, heterogalactans, and heteromannans. These polysaccharides and terpenoids (secondary metabolites) play a pivotal role in glucose homeostasis by inhibiting $\alpha$-glucosidase, assisting glucose transporter 4 actions, and reducing inflammatory factors to improve insulin resistance and lipid metabolism [18,19].

The term "diabetes mellitus" or "DM" is derived from the Greek word "diabetes", which means siphon, to pass through, and the Latin word "mellitus", which means sweet. Diabetes mellitus is a group of non-communicable metabolic diseases characterized by prolonged hyperglycemia resulting from defects in insulin secretion, insulin action, or both [20]. According to American Diabetes Association, 1997 (ADA), diabetes mellitus is classified as type 1 diabetes mellitus (T1DM) (insulin-dependent or juvenile-onset; accounting for 3-10\% cases), type 2 diabetes mellitus (T2DM) (non-insulin-dependent or adult-onset; accounting 85-90\% cases), and gestational diabetes mellitus (hyperglycemia occurs during the second or third trimester of pregnancy and generally resolves after delivery; accounting 2-5\% cases) [21,22]. According to the International Diabetes Federation Data in 2015, 415 million people ( $80 \%$ from middle- and low-income family) was suffering from diabetes, and if it continues to grow will reach 642 million people by 2040 [23]. T1DM is generally accompanied by an autoimmune disorder that triggers the destruction of pancreatic beta cells, alterations in lipid metabolism, enhanced hyperglycemia-mediated oxidative stress, endothelial cell dysfunction, and apoptosis [24,25]. Whereas T2DM causes glucotoxicity, lipotoxicity, endoplasmic reticulum-induced stress, and apoptosis, which finally leads to progressive loss of beta cells [26]. Specific symptom includes polydipsia, polyphagia, polyuria, and nocturia, whereas complication comprises microvascular (retinopathy, nephropathy, and neuropathy) and macrovascular (ischemic heart disease, peripheral vascular disease, and cerebrovascular disease) abnormalities. Several studies have proven that insulin resistance (IR) is the main factor to be concerned about in complications of DM [26-28]. Besides IR, some of the common risk factors for insulin resistance are oxidative stress, hydrolytic enzymatic inhibition, inflammation, genetic habitual, environmental, dyslipidemia, obesity, and epigenetic modulations $[29,30]$. Thus, many pathological factors use to contribute to insulin resistance, although the exact mechanism is not clear yet.

By considering the following factors, the main aim of this review is to elucidate the role of edible mushroom (EM) in diabetes mellitus (DM) treatment by monitoring bioactive compounds of mushrooms, pathophysiology of insulin resistance (IR), and the preventive mechanism of IR using EMs. The data were retrieved by searching scientific publications (research and/or review papers) from databases including Science Direct, PubMed, Embase, and Google Scholar with keywords such as "diabetes", "insulin resistance", "mushroom extracts", "in vivo and in vitro studies", etc. A total of 100 publications were collected, including in vivo and in vitro studies (Figure 1), in which 23 common edible mushroom varieties have been identified (Table 1), and further discussion has been carried out based on scientific literature availability on DM.

We further investigated different species of edible mushrooms and presented the data based on hypoglycemic compounds. After considering the potential bioactive compounds, in vivo and in vitro research analysis was carried out, and the information is represented in Table 2. 


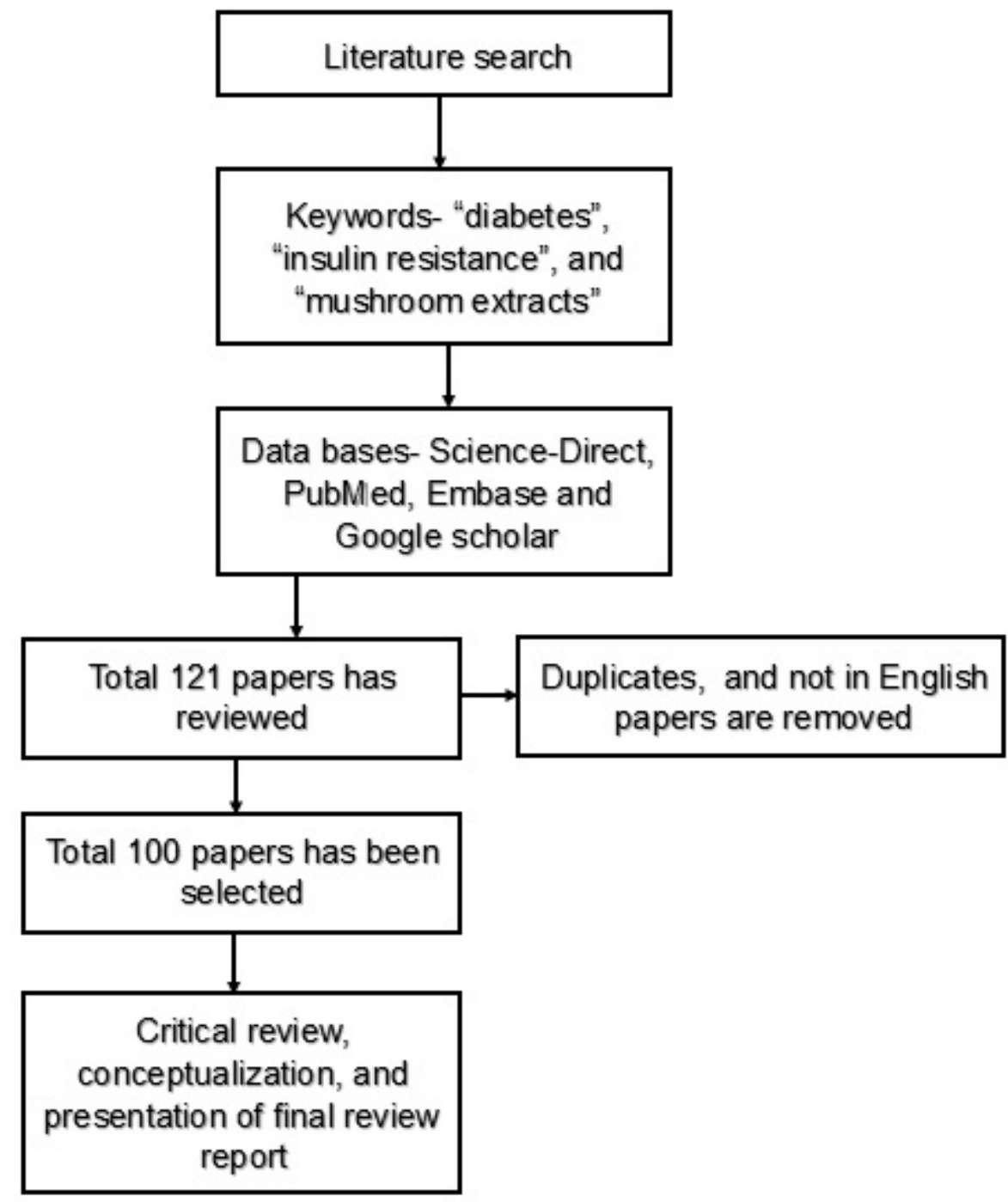

Figure 1. Review research methodology.

Table 1. Types of edible mushrooms.

\begin{tabular}{llll}
\hline S. No. Scientific Name & Vernacular Name & $\begin{array}{l}\text { Cantharellus, } \\
\text { chanterelles }\end{array}$ \\
\hline 1 & Craterellus aureus & Reference \\
\hline 2 & Calvatia rugosa & Puffballs
\end{tabular}


Table 1. Cont.

\begin{tabular}{|c|c|c|c|c|}
\hline S. No. & Scientific Name & Vernacular Name & Photos & Reference \\
\hline 3 & Coprinus comatus & Shaggy mane & & [33] \\
\hline 4 & Pleurotus ostreatus & Oyster mushroom & & [34] \\
\hline 5 & Boletaceae Boletales & Boletes & & [35] \\
\hline
\end{tabular}
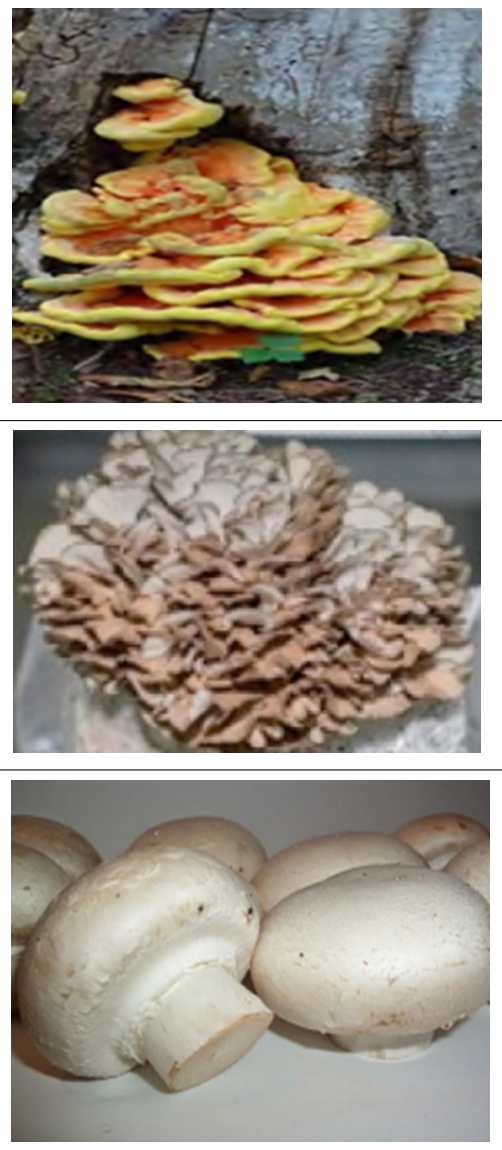
Table 1. Cont.

\begin{tabular}{|c|c|c|c|c|}
\hline S. No. & Scientific Name & Vernacular Name & Photos & Reference \\
\hline 9 & Ramariopsis subarctica & Coral fungi & & [39] \\
\hline 10 & Morachella esculenta & Morels & & {$[40]$} \\
\hline 11 & Hericium erinaceus & Bearded tooth & & {$[41]$} \\
\hline
\end{tabular}

12 Volvariella volvacea Straw mushroom
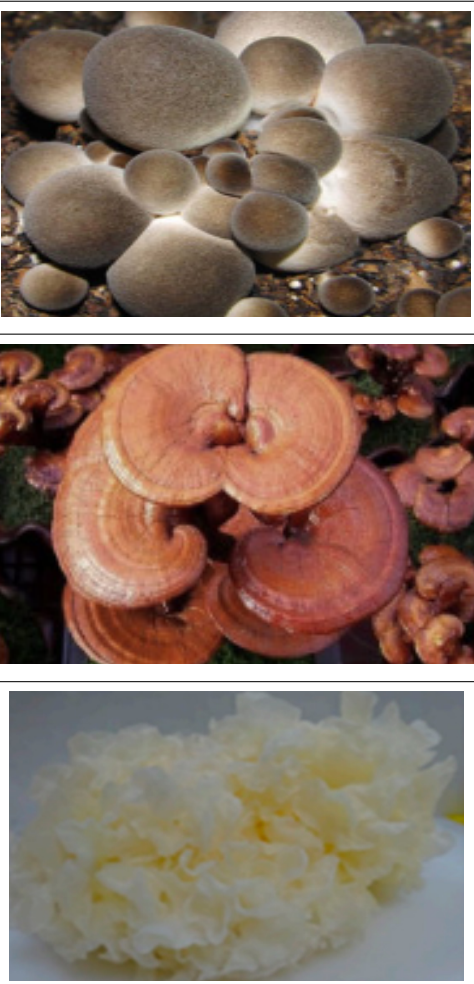
Table 1. Cont.

\begin{tabular}{|c|c|c|c|c|}
\hline S. No. & Scientific Name & Vernacular Name & Photos & Reference \\
\hline 15 & Lentinus concentricus & - & & {$[45]$} \\
\hline 16 & Calocybe indica & Milky white mushroom & & {$[46]$} \\
\hline
\end{tabular}

$17 \quad$ Lenzites betulina

Wood-rooting fungi
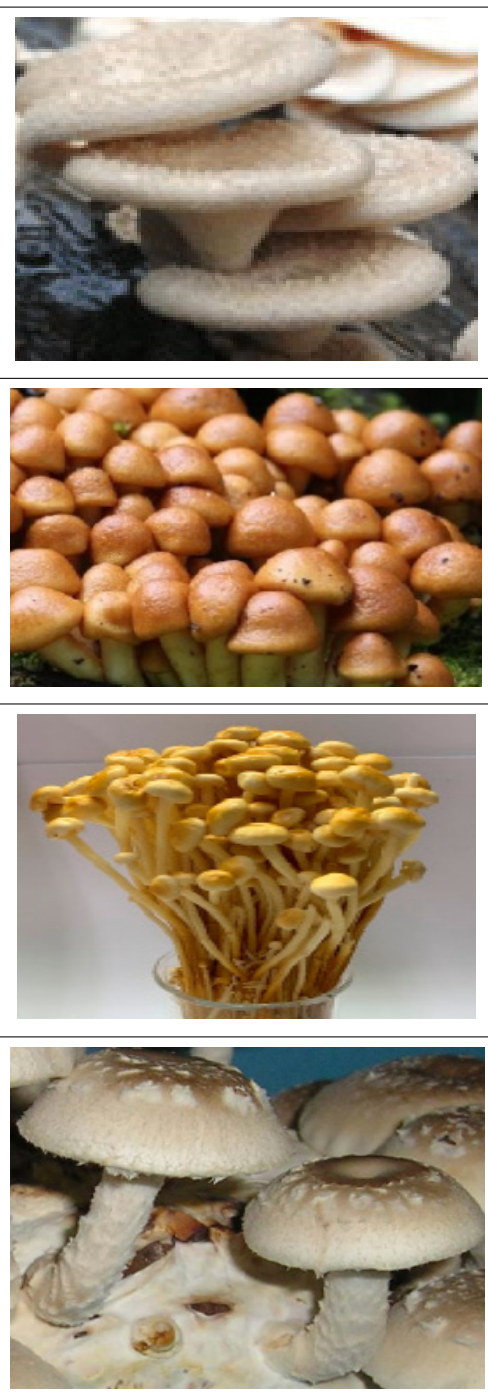
Table 1. Cont.

\begin{tabular}{|c|c|c|c|c|}
\hline S. No. & Scientific Name & Vernacular Name & Photos & Reference \\
\hline 21 & Hypsizygus tessellatus & Buna shimeji & & [51] \\
\hline 22 & Agrocybe aegerita & $\begin{array}{l}\text { Poplar mushroom, } \\
\text { Chestnut mushroom, } \\
\text { Velvet pioppini }\end{array}$ & & [52] \\
\hline 23 & Termitomyces robustus & $\begin{array}{l}\text { Termitomyces } \\
\text { mushrooms }\end{array}$ & & [53] \\
\hline
\end{tabular}

Table 2. Bioactive compounds of edible mushrooms and their effect on in vivo and in vitro study model.

\begin{tabular}{|c|c|c|c|c|c|c|c|}
\hline S. No. & $\begin{array}{l}\text { Scientific } \\
\text { Name }\end{array}$ & Compounds & Functions & Models & $\begin{array}{l}\text { Mushroom } \\
\text { Doses }\end{array}$ & Mechanism/Action & Reference \\
\hline 1 & $\begin{array}{l}\text { Calvatia } \\
\text { gigantea }\end{array}$ & $\begin{array}{l}\text { 2- } \\
\text { Pyrrolidinone, } \\
\text { 1-Dodecene, } \\
\text { ergosterol, } \\
\text { hexadecane, } \\
\text { benzeneacetic } \\
\text { acid. }\end{array}$ & $\begin{array}{l}\text { Anti-diabetic, } \\
\text { antioxidant, } \\
\text { anti-inflammatory. }\end{array}$ & $\begin{array}{l}\text { Alloxan- } \\
\text { induced } \\
\text { diabetic rat. }\end{array}$ & $\begin{array}{l}100,200, \text { and } \\
400 \mathrm{mg} / \mathrm{kg} \\
\text { BW/day. }\end{array}$ & $\begin{array}{l}\text {-Alpha-amylase } \\
\text { inhibitory activity. }\end{array}$ & [54] \\
\hline 2 & $\begin{array}{l}\text { Coprinus } \\
\text { comatus }\end{array}$ & $\begin{array}{l}\text { Mycelium, } \\
\text { polysaccha- } \\
\text { rides. }\end{array}$ & $\begin{array}{l}\text { Immunomodulatory, } \\
\text { anti-diabetic, } \\
\text { antioxidant, } \\
\text { anti-cancer. }\end{array}$ & $\begin{array}{l}\text { High-fat diet } \\
\text { and } \\
\text { STZ-induced } \\
\text { mice. }\end{array}$ & $\begin{array}{l}400 \mathrm{mg} / \mathrm{kg} \\
\text { BW/day. }\end{array}$ & $\begin{array}{l}\text {-Reduce BG level, } \\
\text { relieves oxidative } \\
\text { stress, ameliorate } \\
\text { DN via PI3K/Akt } \\
\text { and } \\
\text { Wnt-1/ } \beta \text {-catenin } \\
\text { pathways. }\end{array}$ & [55] \\
\hline 3 & $\begin{array}{l}\text { Pleurotus } \\
\text { ostreatus, } \\
\text { Pleurotus } \\
\text { pulmonarius, } \\
\text { and Pleurotus } \\
\text { fossulatus }\end{array}$ & $\begin{array}{l}\text { Terpenoids, } \\
\text { heterocyclic } \\
\text { amines, } \\
\text { phenols, } \\
\text { glucan, } \\
\text { proteoglycan. }\end{array}$ & $\begin{array}{l}\text { Anti-cholesterol, } \\
\text { anti-cancer effect, } \\
\text { anti-inflammatory, } \\
\text { anti-diabetic. }\end{array}$ & $\begin{array}{l}\text { STZ and } \\
\text { metformin- } \\
\text { induced } \\
\text { rat. }\end{array}$ & $\begin{array}{l}5-10 \% \text { powder, } \\
50,80,200,250, \\
400, \text { and } 500 \\
\mathrm{mg} / \mathrm{kg} \\
\text { BW/day } \\
\text { extract. }\end{array}$ & $\begin{array}{l}\text {-Decreases serum } \\
\text { glucose level, } \\
\text { alpha-amylase } \\
\text { activity; } \\
\text {-Increases P-AMPK } \\
\text { and GLUT4 in } \\
\text { muscle and } \\
\text { adipose tissue; } \\
\text {-Improves liver } \\
\text { functions and } \\
\text { maintains AST, } \\
\text { ALT, and ALP } \\
\text { levels. }\end{array}$ & {$[56,57]$} \\
\hline
\end{tabular}


Table 2. Cont.

\begin{tabular}{|c|c|c|c|c|c|c|c|}
\hline S. No. & $\begin{array}{l}\text { Scientific } \\
\text { Name }\end{array}$ & Compounds & Functions & Models & $\begin{array}{c}\text { Mushroom } \\
\text { Doses }\end{array}$ & Mechanism/Action & Reference \\
\hline 4 & Boletus & $\begin{array}{l}\text { Tocopherol, } \\
\text { quinic acid, } \\
\text { hydroxy } \\
\text { benzoic acid. }\end{array}$ & $\begin{array}{l}\text { Antioxidant, } \\
\text { anti-inflammatory, } \\
\text { hypoglycemic. }\end{array}$ & $\begin{array}{l}\text { STZ-induced } \\
\text { rat. }\end{array}$ & $\begin{array}{l}400 \mathrm{mg} \\
\text { extract/kg } \\
\text { BW/day. }\end{array}$ & $\begin{array}{l}\text {-Decreases TC, TG, } \\
\text { TNF-alpha, and } \\
\text { NF-kB level; } \\
\text {-Maintains MDA } \\
\text { level; } \\
\text {-Improves } \\
\text { antioxidant (CAT, } \\
\text { SOD, and GSH) } \\
\text { and CYP7A1 } \\
\text { levels. }\end{array}$ & [58] \\
\hline 5 & Grifora frondosa & $\begin{array}{l}\text { Grifolan } \\
\text { polysaccha- } \\
\text { ride, } \\
\text { D-fraction, } \\
\text { MD-fraction, } \\
\text { polysaccha- } \\
\text { ride, } \\
\text { galactoman- } \\
\text { nan, } \\
\text { heteroglycan. }\end{array}$ & $\begin{array}{l}\text { Hypoglycemic, } \\
\text { anti-inflammatory, } \\
\text { anti-modulatory, } \\
\text { anti-tumor. }\end{array}$ & $\begin{array}{l}\text { STZ, alloxan- } \\
\text { induced rat } \\
\text { and } \\
\text { palmitate- } \\
\text { induced C2C12 } \\
\text { cells. }\end{array}$ & $\begin{array}{l}0.5-20 \mu \mathrm{M} \\
\text { (introduced to } \\
\text { C2C12 cell), } \\
112.5,200, \text { and } \\
675 \mathrm{mg} / \mathrm{kg} \\
\mathrm{BW} / \mathrm{day} \\
\text { extract } \\
\text { (introduced to } \\
\text { STZ- and } \\
\text { alloxan- } \\
\text { induced } \\
\text { rat). }\end{array}$ & $\begin{array}{l}\text {-Inhibits serum } \\
\text { levels of IL-2, IL-6; } \\
\text {-Modulates serum } \\
\text { level of oxidant } \\
\text { factors such as } \\
\text { superoxide } \\
\text { dismutase, } \\
\text { glutathione } \\
\text { peroxidase, } \\
\text { catalase, } \\
\text { malondialdehyde, } \\
\text { and reactive } \\
\text { oxygen species; } \\
\text {-Increases glucose } \\
\text { uptake and } \\
\text { decreases ROS } \\
\text { formation and } \\
\text { up-regulates IRS-1, } \\
\text { p-IRS-1, PI3K, Akt, } \\
\text { pAkt and GLUT4 } \\
\text { protein, and } \\
\text { down-regulates } \\
\text { p-JNK and p-p38 } \\
\text { expression; } \\
\text {-Improves insulin } \\
\text { resistance and gut } \\
\text { microflora content. }\end{array}$ & {$[59,60]$} \\
\hline 6 & $\begin{array}{l}\text { Agricus } \\
\text { bisporus }\end{array}$ & $\begin{array}{l}\text { Pyrogallol, } \\
\text { hydroxyben- } \\
\text { zoic acid } \\
\text { derivatives } \\
\text { glavonoid. }\end{array}$ & $\begin{array}{l}\text { Anti-inflammatory, } \\
\text { anti-diabetic. }\end{array}$ & $\begin{array}{l}\text { Alloxan- } \\
\text { induced } \\
\text { rat. }\end{array}$ & $\begin{array}{l}15-30 \text { g/day, } \\
250,500 \text { and } \\
750 \mathrm{mg} / \mathrm{kg} \\
\text { BW/day. }\end{array}$ & $\begin{array}{l}\text {-Improves } \\
\text { antioxidant (SOD) } \\
\text { level; } \\
\text {-Improves ALP, } \\
\text { AST, ALT level; } \\
\text {-Reduces } \\
\text { hyperlipidemia. }\end{array}$ & {$[38,61]$} \\
\hline 7 & $\begin{array}{l}\text { Morachella } \\
\text { esculenta }\end{array}$ & $\begin{array}{l}\text { Polysaccharides } \\
\text { (mannose, } \\
\text { galactose, and } \\
\text { glucose), } \\
\text { phenolic } \\
\text { compounds. }\end{array}$ & $\begin{array}{l}\text { Antioxidant, } \\
\text { anti-inflammation, } \\
\text { immunoregulation, } \\
\text { hypoglycemic. }\end{array}$ & - & - & - & {$[62]$} \\
\hline 8 & $\begin{array}{l}\text { Hericium } \\
\text { erinaceus }\end{array}$ & $\begin{array}{l}\text { 4-chloro-3,5- } \\
\text { dimethoxybenzoic } \\
\text { acid-O-arabitol } \\
\text { ester, } \\
2 \text { - } \\
\text { hydroxymethyl- } \\
\text { 5- } \alpha \text {-hydroxy- } \\
\text { ethyl- } \gamma \text { - } \\
\text { pyranone, } \\
\text { 6-methyl-2,5- } \\
\text { dihydroxymethyl- } \\
\gamma \text {-pyranone, } \\
\text { 4-chloro-3,5- } \\
\text { dihydroxybenzald } \\
\text { 4-chloro-3,5- } \\
\text { dihydroxybenzyl } \\
\text { alcohol. }\end{array}$ & $\begin{array}{l}\text { Immunomodulatory, } \\
\text { hypoglycemic, } \\
\text { antimicrobial. }\end{array}$ & $\begin{array}{l}\text { STZ-treated } \\
\text { rat. }\end{array}$ & $\begin{array}{l}400-600 \\
\mathrm{mg} / \mathrm{kg} \\
\mathrm{BW} / \text { day. }\end{array}$ & $\begin{array}{l}\text {-Reduces blood } \\
\text { glucose, BUN, and } \\
\text { CRT level; } \\
\text {-Maintains ALP, } \\
\text { ALT, and AST } \\
\text { levels; } \\
\text {-Improves } \\
\text { antioxidant level } \\
\text { (SOD, glutathione). }\end{array}$ & {$[63,64]$} \\
\hline
\end{tabular}


Table 2. Cont.

\begin{tabular}{|c|c|c|c|c|c|c|c|}
\hline S. No. & $\begin{array}{l}\text { Scientific } \\
\text { Name }\end{array}$ & Compounds & Functions & Models & $\begin{array}{l}\text { Mushroom } \\
\text { Doses }\end{array}$ & Mechanism/Action & Reference \\
\hline 9 & $\begin{array}{l}\text { Ganoderma } \\
\text { lucidium }\end{array}$ & $\begin{array}{l}\text { Ganoderic acid, } \\
\text { danoderiol, } \\
\text { danderenic } \\
\text { acid, } \\
\text { lucidenic acid, } \\
\text { ganoderma } \\
\text { leucidum } \\
\text { polysaccha- } \\
\text { ride. }\end{array}$ & $\begin{array}{l}\text { Anti-diabetic, } \\
\text { anti-inflammatory. }\end{array}$ & $\begin{array}{l}\text { Metformin-, } \\
\text { STZ-, and high- } \\
\text { fat-treated } \\
\text { rat. }\end{array}$ & $\begin{array}{l}1-3 \% \\
\text { freeze-dried } \\
\text { mushroom, 25, } \\
50,100,250, \\
500 \text { and } \\
1000 \mathrm{mg} / \mathrm{kg} \\
\text { BW/day } \\
\text { extract. }\end{array}$ & $\begin{array}{l}\text {-Decreases HBA1c } \\
\text { and improves AST, } \\
\text { ALT level. }\end{array}$ & {$[60,65]$} \\
\hline 10 & $\begin{array}{l}\text { Lenzites } \\
\text { betulina }\end{array}$ & $\begin{array}{l}\alpha \text {-glucan, } \\
\beta \text {-glucan, } \\
\beta \text {-glucan } \\
\text { protein, } \\
\text { galacturonic } \\
\text { acid. }\end{array}$ & $\begin{array}{l}\text { Antioxidant, } \\
\text { anti-hyperglycaemic, } \\
\text { anti-inflammatory, } \\
\text { anti-proliferative, } \\
\text { antibacterial. }\end{array}$ & - & - & - & [66] \\
\hline 11 & $\begin{array}{l}\text { Flammulina } \\
\text { velutipes }\end{array}$ & $\begin{array}{l}\text { Flammulinolide, } \\
\text { enokipodin, } \\
\text { proflamin, } \\
\text { other polysac- } \\
\text { charide. }\end{array}$ & $\begin{array}{l}\text { Anti-tumor, } \\
\text { anti-hypertension, } \\
\text { anti- } \\
\text { hypercholesterolemia, } \\
\text { hypoglycemic. }\end{array}$ & $\begin{array}{l}\text { STZ-induced } \\
\text { mice. }\end{array}$ & $\begin{array}{l}400 \mathrm{mg} / \mathrm{kg}, \\
600 \mathrm{mg} / \mathrm{kg}, \\
\text { and } 800 \mathrm{mg} / \mathrm{kg} \\
\text { BW/ day. }\end{array}$ & $\begin{array}{l}\text {-Improves } \\
\text { PI3K/AKT } \\
\text { pathway. }\end{array}$ & {$[67,68]$} \\
\hline 12 & Lentinula edodes & $\begin{array}{l}\text { Lentinan, } \\
\text { eritadenina. }\end{array}$ & $\begin{array}{l}\text { Anti-carcinogenic, } \\
\text { antioxidant, } \\
\text { hypocholesterolemic } \\
\text { action. }\end{array}$ & $\begin{array}{l}\text { STZ-treated rat } \\
\text { (gestational } \\
\text { diabetes). }\end{array}$ & $\begin{array}{l}100 \mathrm{mg} / \mathrm{kg} \\
\text { BW/day. }\end{array}$ & $\begin{array}{l}\text {-Improves } \\
\text { maternal insulin } \\
\text { level; } \\
\text {-Reduces } \\
\text { aminotransferase, } \\
\text { aspartate } \\
\text { aminotransferase, } \\
\text { triglyceride, and } \\
\text { total cholesterol } \\
\text { level. }\end{array}$ & {$[69,70]$} \\
\hline 13 & $\begin{array}{l}\text { Termitomyces } \\
\text { robustus }\end{array}$ & $\begin{array}{l}\gamma \text { glutamyl- } \beta- \\
\text { phenylethylamine, } \\
\text { tryptophan 1,4- } \\
\text { hydroxyphenylacet } \\
\text { acid, hydrox- } \\
\text { yphenyl } \\
\text { propionic acid } \\
\text { and } \\
\text { phenyllactic } \\
\text { acid. }\end{array}$ & Hypoglycemic effect. & $\begin{array}{l}\text { In vitro assay, } \\
\text { Wister rat. }\end{array}$ & $\begin{array}{l}\text { Crude extract } \\
78.05 \text { and } \\
86.10 \mu \mathrm{g} / \mathrm{mL} . \\
500,1000, \text { and } \\
1500 \mathrm{mg} / \mathrm{kg} \\
\text { BW/day. } \\
\text { In vitro assay, } \\
\text { rate acute } \\
\text { toxicity test } \\
\text { (10 g/kg } \\
\text { extract) and } \\
\text { subacute } \\
\text { toxicity test } \\
\text { (500, 1000, and } \\
1500 \mathrm{mg} / \mathrm{kg}) \\
\text { BW/day. }\end{array}$ & $\begin{array}{l}\text { - } \alpha \text {-glucosidase and } \\
\alpha \text {-amylase } \\
\text { inhibitory activity. }\end{array}$ & {$[15,71]$} \\
\hline
\end{tabular}

DN-diabetic nephropathy, Wnt-1-wingless-related integration site, P-AMPK-activated protein kinase GLUT4-glucose transporter type 4, TC—-total cholesterol, STZ—streptozotocin, FBG-fasting blood glucose, BGL_blood glucose level, TG - triglyceride, CRT_creatinine, BUN-blood urea nitrogen, AST-aspartate aminotransferase, ALT-alanine aminotransferase, ALP - alkaline phosphatase, TNF-alpha-tumor necrosis factor alpha, NF-kB — nuclear factor kappa B, MDA — malondialdehyde, CAT—chloramphenicol acetyltransferase, SODsuperoxide dismutase, GSH—glutathione, CYP7A1—cholesterol 7-alpha-monooxygenase gene, IL-6-interleukin 6, IL-2 -interleukin 2, IRS-1—insulin receptor substrate 1, PI3K-phosphoinositide-3-kinase, Akt-protein kinase B, p-JNK-c-Jun N-terminal kinase, HBA1c_-glycosylated hemoglobin, PGL_plasma glucose level.

\section{Diabetes Mellitus and Insulin Resistance}

Nowadays, the global incidence of diabetes is escalating in both developed and developing countries. Generally, obesity is directly involved in the pathogenesis of T2DM along with insulin resistance (IR), and the incidence of IR in T1DM is also increasing frequently. Therefore, it is crucial to understand the mechanism of glucose homeostasis and insulin resistance.

Pancreatic cell plays an important role in glucose homeostasis. T2DM reduces insulin secretion by $50 \%$ and also lessens the sensitivity of peripheral tissue to insulin up to $70 \%$. So, the study on IR has a great clinical significance in medical interventions. Basically, insulin exerts its effect through phosphorylation of phosphoinositide 3-kinase (PI3K) and protein kinase B (PkB, Akt) [72,73]. Next, through PI3k phosphorylation, it activates 
glucose transporter 4 (GLUT4). Other factors involved in insulin action and carbohydrate metabolism are serine/threonine kinase Akt phosphorylates GSk3 $\beta$, FOXOs, IRS (insulinregulated sequence), and SREBP-1c (sterol-regulated element-binding protein transcription factors) (Figure 2) [74].

Insulin sensitivity can be defined as a pathological condition in which normal plasma insulin level in targeted tissues fails to maintain normal blood glucose levels via enhancement of endogenous glucose production, lipogenesis, and glycolysis [75]. Thereby, IR refers to a state that exhibits the reduced biological effect of a given insulin concentration. So, IR increases insulin secretion and thus enhances fasting plasma insulin level, which is finally considered IR [76]. Moreover, IR is not only associated with DM but also several pathological conditions such as cardiovascular disease, non-alcoholic fatty liver disease, and cancer as well [77].

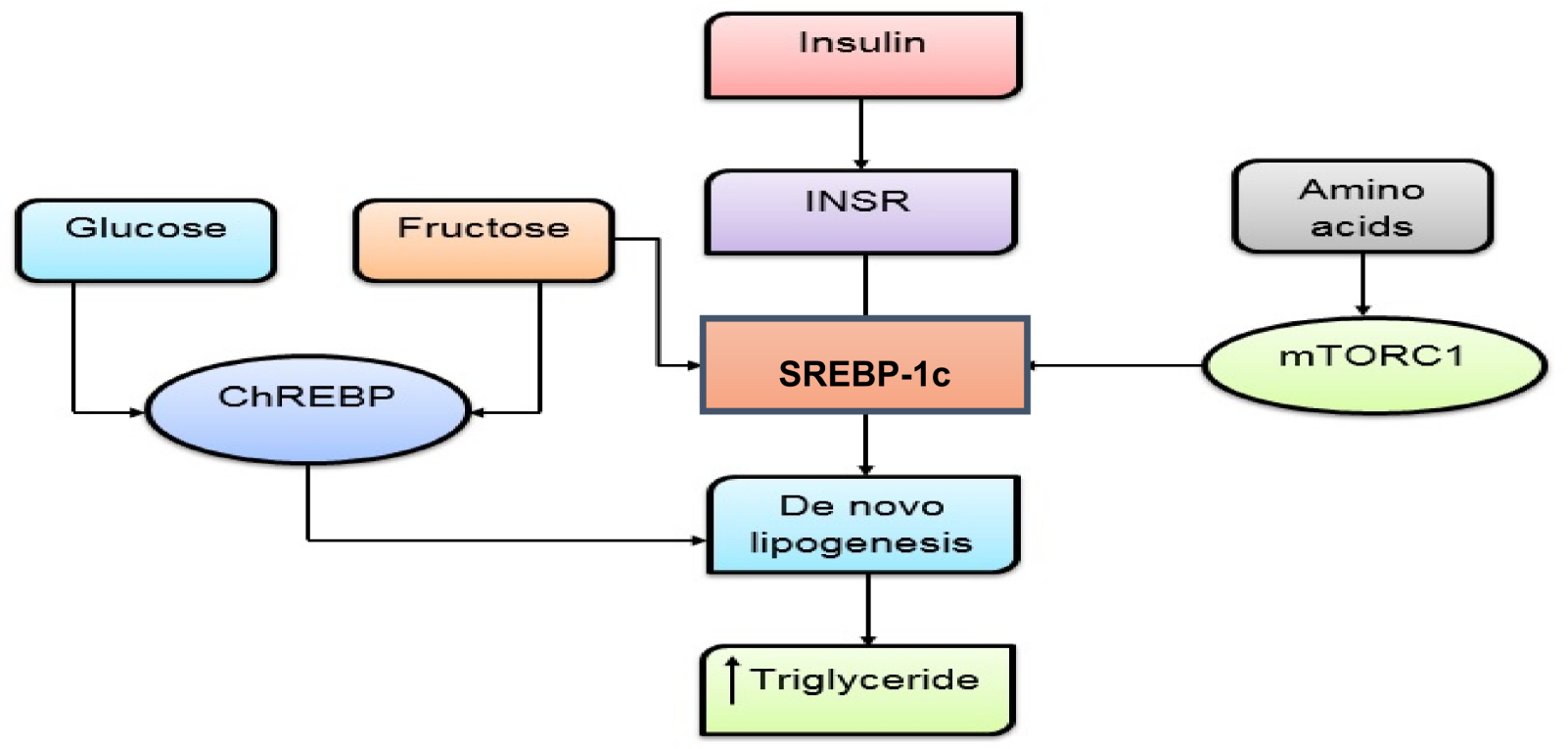

Figure 2. Relationship between liver insulin resistance and macronutrients. ChREBP—carbohydrate response element-binding protein, INSR-insulin receptor, SREBP-1c-sterol-regulated elementbinding protein, mTORC1-mammalian target of rapamycin complex 1 or mechanistic target of rapamycin complex 1 .

\section{Diabetes Mellitus and Insulin Resistance Preventive Mechanism by Edible Mushroom}

Mushrooms possess medicinal components due to the presence of different types of secondary metabolites such as polysaccharides, lectins, lactones, terpenoids, alkaloids, antibiotics, and metal-chelating agents [78]. Mechanism of insulin resistance using mushroom is as follows.

\subsection{Blood Glucose-Lowering Effect of Polysaccharide}

Polysaccharides are ubiquitous biopolymers made up of simple sugar or monosaccharides linked together by glycosidic linkage. Based on structure, polysaccharides are divided into two groups-homopolysaccharides (linear or highly branched, composed of the same monosaccharide molecules) and heteropolysaccharides (made up of different monosaccharide units) [79]. Earlier studies show that mushrooms are rich in $\beta$-D-glucans, $\beta$-glucan, a type of dietary fiber that shows promising health benefits against T2DM [80]. Mushroom extracts from Pleurotus species [56], Boletu [58], Grifola frondosa [81], Agaricus bisporus [38], Hericium erinaceus [63], and Ganoderma lucidum [82] regulate the synthesis of glycogen and lowers blood glucose levels by regulating gene expression of glycogen synthase kinase (GSK-3 $\beta$ ), glycogen synthase (GS) and glucose transporter 4 (GLUT4) 
in liver and muscle. Therefore GSK-3 $\beta$ could be identified as an insulin-mediated GSregulated negative regulator [83]. Other mechanisms by which polysaccharides prevent insulin resistance are by reducing $\alpha$-amylase activity, $\alpha$-glucosidase activities, and finally facilitating PI3K/AKT pathways, which are directly involved in glucose homeostasis [78].

Other mechanisms by which polysaccharides lowers blood glucose level is as follows-

\subsubsection{Inhibition of Glucose Absorption}

Due to the presence of water-soluble dietary fiber, mushrooms delay glucose absorption and slow down digestion rates, thereby postprandial glucose upsurge [84,85]. Several studies have proven that mushrooms, especially Pleurotus spp. [56], Grifola frondosa [81], Agaricus bisporus [38], Hericium erinaceus [63], and Ganoderma lucidum [65] have significant blood glucose-lowering effect, as they delay the absorption of glucose and therefore improves hyperglycaemic condition [78].

\subsubsection{Maintains Pancreatic $\beta$ Cells Activity}

Mushrooms polysaccharides ( $\beta$-D-glucan) act as a potent immune modulator and prevent activations of pro-inflammatory cytokines by reducing the activity of NF-kB, and it also outlawed oxidative damage. Bioactive compounds from mushrooms, especially polysaccharides, prevent pancreatic $\beta$-cell apoptosis and hinder glucotoxicity [80]. Studies also showed that mushroom extracts from Pleurotus spp., Boletus, Agaricus bisporus, and Hericium erinaceus have a significant effect on $\beta$-cell functionality and thus maintain $\beta$-cell growth [63].

\subsection{Blood Glucose-Lowering Effect of Terpenoids}

Enzymes like $\alpha$-glucosidase and $\alpha$-amylase hydrolyze oligosaccharides to monosaccharides and increase blood glucose levels [86]. Mushrooms terpenoids (monoterpenes, diterpenes, sesquiterpenes, and triterpenes) (Figure 3) [19] from Pleurotus spp. [56], Laetiporus sulphurous [87], Tremella fuciformis [88], Ganoderma lucidum [60], and Pholiota microspore [89] are believed to have an $\alpha$-glucosidase inhibitory activity that prevents the formation of monosaccharide molecules and facilitates glycogen formation in the liver and muscle.

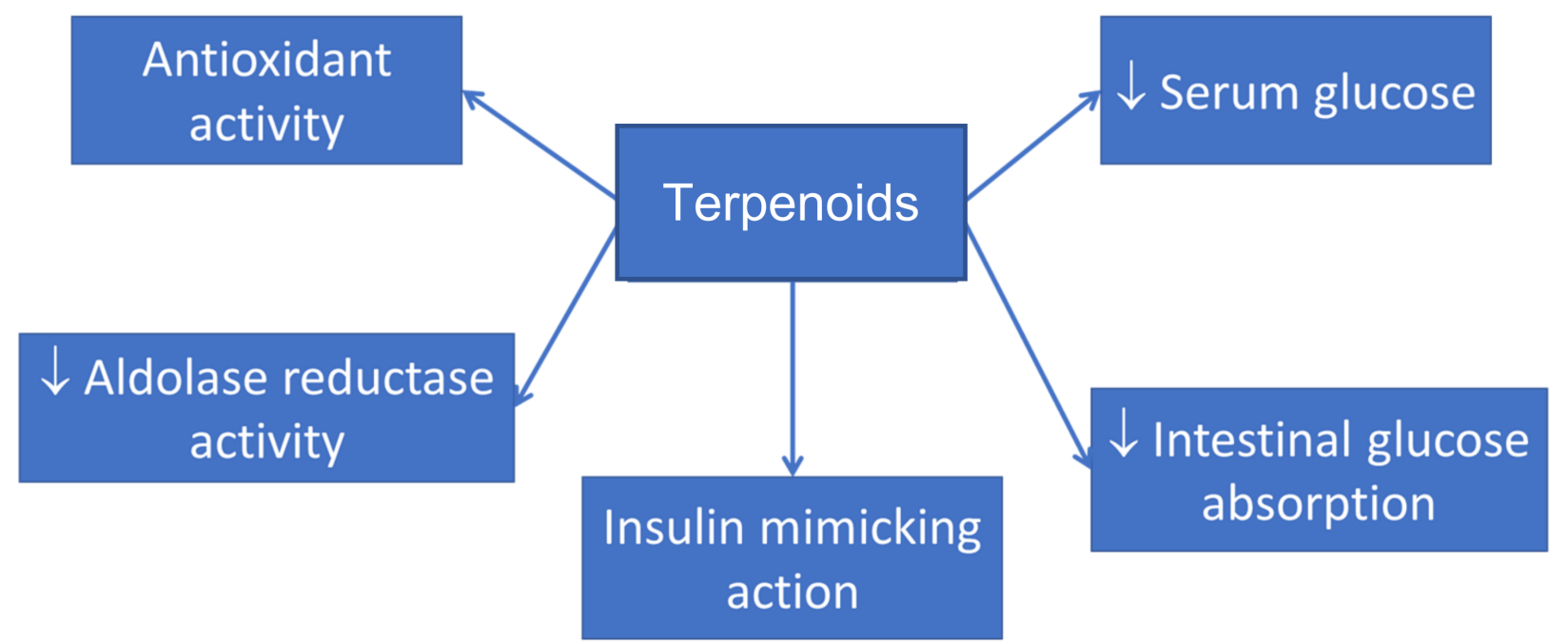

Figure 3. Beneficial effects of mushroom terpenoids (monoterpenes, diterpenes, sesquiterpenes, and triterpenes).

\subsection{Role of Vitamin D in Blood Glucose Regulations}

Mushroom resides from the fungal kingdom, and unlike a plant, it has a high concentration of ergosterol in the cell wall. In the presence of sunlight, ergosterol in the mushroom cell wall is transformed to pre-vitamin D2 and thermally isomerized to ergocalciferol, 
commonly known as vitamin D2 [90]. 1, $5(\mathrm{OH}) 2 \mathrm{D}$ or 1,25-dihydroxy vitamin D plays an important role in glucose homeostasis. It also protects $\beta$-cells from harmful immune attacks by its direct action on $\beta$-cells, and indirect action on different immune cells, including inflammatory macrophages, dendritic cells, and a variety of T cells [91]. Molecular mechanisms by which vitamin D maintains insulin secretion is by regulating intracellular calcium concentration. Vitamin D, with the help of calbindin, facilitates $\mathrm{Ca}+$ absorption, PKA activation, and PLC synthesis, which facilitates calcium secretion that, in consequence, leads to insulin secretion [92] (Figure 4).

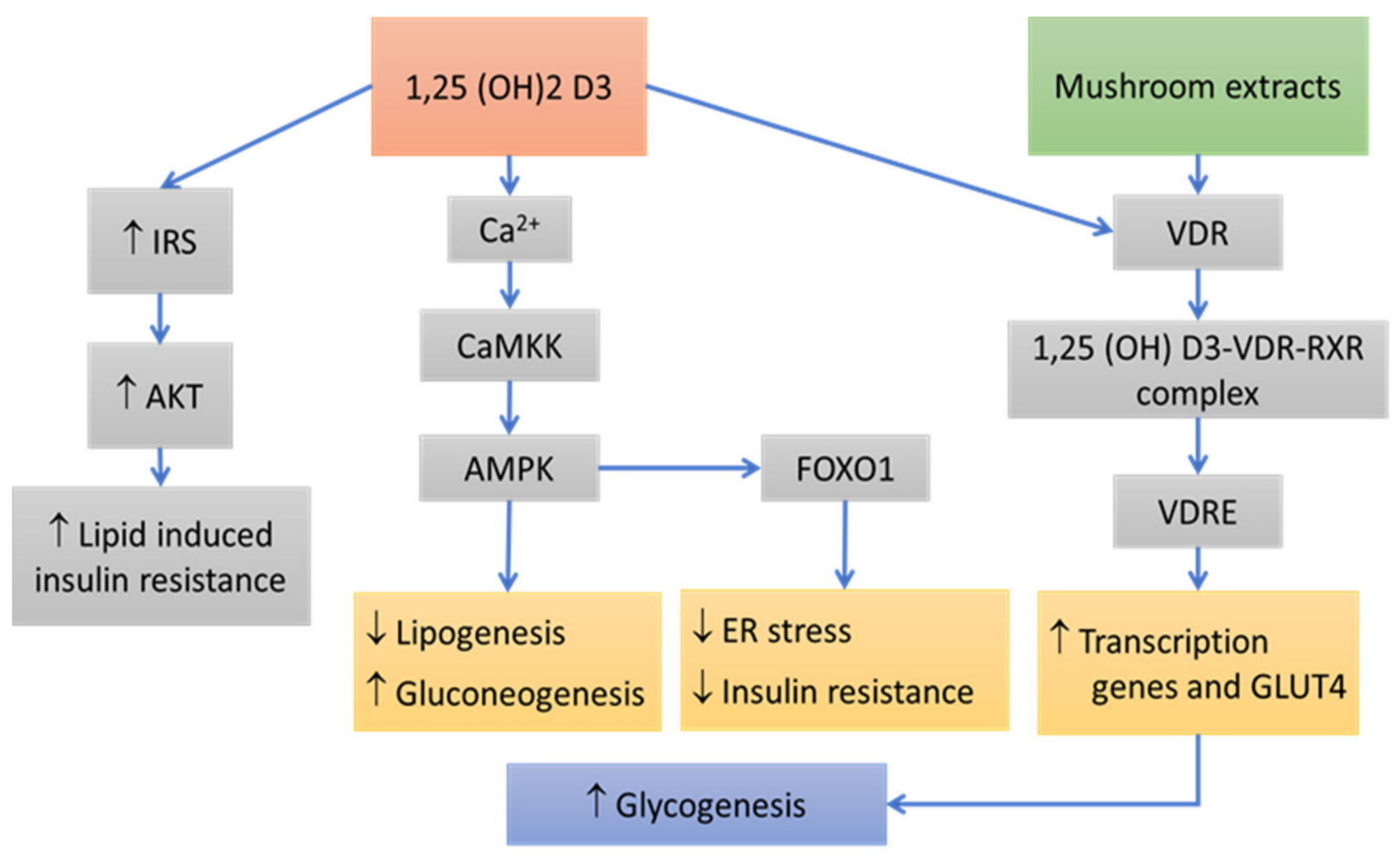

Figure 4. Relationship between vitamin D, mushroom extracts, and insulin resistance. IRS-insulin receptor substrate, AKT-protein kinase B, CaMKK—calcium/calmodulin-dependent protein kinase, AMPK—activated protein kinase, FOXO1—forkhead box transcription factor 1, VDR-, VDREvitamin D-responsive elements.

Subsequently, the genomic mechanism of vitamin $\mathrm{D}$ action is mediated by the vitamin $\mathrm{D}$ receptor (VDR). The active form of vitamin D 1,25 $(\mathrm{OH}) 2 \mathrm{D} 3 \mathrm{binds}$ to VDR and forms a heterodimer with the retinoid receptors (RXR). The complex of 1,25 (OH)2 D3-VDR-RXR is translocated to the nucleus and binds to vitamin D-responsive elements (VDRE), thereby facilitating epigenetic modulations and preventing insulin resistance [93].

In short, vitamin D shows its function in different ways, such as inherited gene polymorphism, immune-regulatory functions, proliferation preventive actions, anti-inflammatory activities (decreases the functions of pro-inflammatory cytokines, TNF- $\alpha$, IL- $8 b$, and IL-6), and finally regulates the production of adipokines and thereby prevents insulin resistance (via IRS, AKT, PPARy, and VDRE gene regulations) [94] (Table 3). 
Table 3. Functions of vitamin D on different organs [94].

\begin{tabular}{ll}
\hline \multicolumn{1}{c}{ Organ Name } & \multicolumn{1}{c}{ Functions } \\
\hline Pancreas & $\begin{array}{l}\text { Increases insulin secretion and enhances the transformation of } \\
\text { pro-insulin to insulin }\end{array}$ \\
\hline Skeletal muscle & Through VDR expression maintains glucose homeostasis \\
\hline Skin & Improves skin micro-circulations and fasten wound healing \\
\hline Nervous system & Improves nerve conduction and shows the analgesic effect \\
\hline Kidney & Controls urinary albuminuria \\
\hline Retina & Defend against oxidative stress \\
\hline
\end{tabular}

The bioavailability of vitamin $\mathrm{D}$ in diabetic treatment is still controversial, and based on the available data, it is not yet transparent among scientists [95]. However, recent findings from randomized placebo trial data by Urbain et al., 2011 shows that button mushroom treated with UV-B can improve vitamin D2 bioavailability among human subjects, and the significant value does not differ with vitamin D2 supplements [96]. In addition, studies by Wenclewska et al., 2019; Mutt et al., 2020; Hajj et al., 2020; and Cojic et al., 2021 demonstrated the positive impact of vitamin D supplementation (2000IU and 30,000IU) on T2DM, which requires further trials [97-100]. Therefore, the question remains the exact mechanism and dose-dependent action of vitamin $\mathrm{D}$ on diabetes mellitus treatment.

\section{Conclusions}

In the present review, a total of 23 edible mushrooms have been scrutinized to review the medicinal components and diabetes mellitus preventive activities. Among all the varieties, 13 varieties have anti-diabetic properties. Mushrooms' anti-diabetic activity is generally dependent on their polysaccharide ( $\beta$-D-glucan) and vitamin D contents. Therefore, in vivo and in vitro studies show that among 13 varieties, only 11 verities demonstrated anti-diabetic activities. Additionally, the most widely studied variations are Pleurotus, Grifola, and Ganoderma species. Thus, based on the available data, it can be concluded that mushrooms are beneficial fungi that have a great potential to treat non-communicable diseases, especially diabetes. However, future research work is necessary for the clinical field such as animal study (in vivo and in vitro), enzyme inhibition assay ( $\alpha$-amylase, $\alpha$ glucosidase, pancreatic lipase, and DPP4-dipeptidyl peptidase 4), human trial, pilot study, as well as prospective and retrospective studies to use the possible therapeutic applications of mushrooms. Special focus must be given to the link between vitamin D and insulin resistance along with enzymatic assay by considering its potential effect. Furthermore, without adequate investigation, the conclusion is relatively challenging. So, further revelation is recommended in the clinical probe.

Author Contributions: Conceptualization, S.-C.L. and A.D.; validation, C.-M.C. and S.-C.M.; drafting of the manuscript, S.-C.L. and A.D.; critical revision of the manuscript, S.-H.Y. and Y.-M.J., and final approval of the published version, S.-C.L. All authors have read and agreed to the published version of the manuscript.

Funding: This study was supported by the Council of Agriculture in Taiwan. The funding number is 111AS-11.1.2-CI-C1.

Institutional Review Board Statement: Not applicable.

Informed Consent Statement: Not applicable.

Data Availability Statement: The data that support the findings of this study are available from the corresponding author upon reasonable request.

Acknowledgments: We thank Seng-Kai Vong and Hsin-Yi Huang for their technical assistance.

Conflicts of Interest: The authors declare no conflict of interest. 


\begin{abstract}
Abbreviations
EM-edible mushroom, IR—insulin resistance, DM-diabetes mellitus, T1DM-type 1 diabetes mellitus, T2DM-type 2 diabetes mellitus, PI3k-phosphoinositide 3-kinase, PkB-protein kinase B, GSK-3 $\beta$-glycogen synthase kinase-3 $\beta$, GS - glycogen synthase, FOXO-forkhead box transcription factor, SREBP-1c-sterol-regulated element-binding protein, PkA—protein kinase, PLC - phospholipase C, RXR—retenoid receptor, VDRE—vitamin D-responsive elements, IRS—insulin receptor substrate, PPARy-peroxisome proliferator-activated receptor gamma, TNF- $\alpha$-tumor necrosis factor alpha, IL-8b-interleukin 8 receptor, IL-6 -interleukin 6 receptor, CaMKK—calcium/calmodulin-dependent protein kinase, AMPK-activated protein kinase, 1,25 (OH)2 D3—calcitriol/1,25 dihydroxycholecalciferol, ChREBP—carbohydrate response element-binding protein, mTORC1—mammalian target of rapamycin complex 1 or mechanistic target of rapamycin complex 1 .
\end{abstract}

\title{
References
}

1. Ukwuru, M.; Muritala, A.; Eze, L. Edible and non-edible wild mushrooms: Nutrition, toxicity and strategies for recognition. J. Clin. Nutr. Metab. 2018, 2, 9.

2. Ślusarczyk, J.; Adamska, E.; Czerwik-Marcinkowska, J. Fungi and algae as sources of medicinal and other biologically active compounds: A review. Nutrients 2021, 13, 3178. [CrossRef] [PubMed]

3. Hoa, H.T.; Wang, C.L.; Wang, C.H. The effects of different substrates on the growth, yield, and nutritional composition of two oyster mushrooms (Pleurotus ostreatus and Pleurotus cystidiosus). Mycobiology 2015, 43, 423-434. [CrossRef]

4. Koutrotsios, G.; Tagkouli, D.; Bekiaris, G.; Kaliora, A.; Tsiaka, T.; Tsiantas, K.; Chatzipavlidis, I.; Zoumpoulakis, P.; Kalogeropoulos, N.; Zervakis, G.I. Enhancing the nutritional and functional properties of Pleurotus citrinopileatus mushrooms through the exploitation of winery and olive mill wastes. Food Chem. 2022, 370, 131022. [CrossRef]

5. Yadav, D.R. Edible Mushrooms. 2010. Available online: https://www.researchgate.net/publication/322210506_EDIBLE_ MUSHROOMS?channel=doi\&linkId=5a4bbf790f7e9b8284c2ded5\&showFulltext=true (accessed on 19 January 2022).

6. Das, A.K.; Nanda, P.K.; Dandapat, P.; Bandyopadhyay, S.; Gullón, P.; Sivaraman, G.K.; McClements, D.J.; Gullón, B.; Lorenzo, J.M. Edible mushrooms as functional ingredients for development of healthier and more sustainable muscle foods: A flexitarian approach. Molecules 2021, 26, 2463. [CrossRef] [PubMed]

7. Sharma, V.P.; Barh, A.; Bairwa, R.; Annepu, S.K.; Thakur, B.; Kamal, S. Enoki mushroom (Flammulina velutipes (Curtis) Singer) breeding. In Advances in Plant Breeding Strategies: Vegetable Crops; Springer: Cham, Switzerland, 2021; pp. $423-441$.

8. Tiane, C.; Finimundy, T.; José, A.; Dillon, P.; Antônio, J.; Henriques, J.A.; Ely, M. A review on general nutritional compounds and pharmacological properties of the Lentinula edodes mushroom. Food Nutr. Sci. 2014, 5, 1095-1105. [CrossRef]

9. Song, Q.; Teng, A.G.; Zhu, Z. Chemical structure and inhibition on $\alpha$-glucosidase of a novel polysaccharide from Hypsizygus marmoreus. J. Mol. Struct. 2020, 1211, 128110. [CrossRef]

10. Kleftaki, S.A.; Simati, S.; Amerikanou, C.; Gioxari, A.; Tzavara, C.; Zervakis, G.I.; Kalogeropoulos, N.; Kokkinos, A.; Kaliora, A.C. Pleurotus eryngii improves postprandial glycaemia, hunger and fullness perception, and enhances ghrelin suppression in people with metabolically unhealthy obesity. Pharmacol. Res. 2022, 175, 105979. [CrossRef]

11. He, X.; Wang, X.; Fang, J.; Chang, Y.; Ning, N.; Guo, H.; Huang, L.; Huang, X.; Zhao, Z. Polysaccharides in Grifola frondosa mushroom and their health promoting properties: A review. Int. J. Biol. Macromol. 2017, 101, 910-921. [CrossRef]

12. Diyabalanage, T.; Mulabagal, V.; Mills, G.; Dewitt, D.; Nair, M. Health-beneficial qualities of the edible mushroom, Agrocybe aegerita. Food Chem. 2008, 108, 97-102. [CrossRef]

13. Rahman, M.; Akter, R. Diabetes ameliorating effect of mushrooms. J. Nov. Physiother. 2021, 2, 9-13.

14. Thu, Z.M.; Myo, K.K.; Aung, H.T.; Clericuzio, M.; Armijos, C.; Vidari, G. Bioactive phytochemical constituents of wild edible mushrooms from southeast Asia. Molecules 2020, 25, 1972. [CrossRef] [PubMed]

15. Ogbole, O.O.; Noleto-Dias, C.; Kamdem, R.S.T.; Akinleye, T.E.; Nkumah, A.; Ward, J.L.; Beale, M.H. $\gamma$-Glutamyl- $\beta$ phenylethylamine, a novel $\alpha$-glucosidase and $\alpha$-amylase inhibitory compound from Termitomyces robustus, an edible Nigerian mushroom. Nat. Prod. Res. 2021, 1-11. [CrossRef]

16. Ma, G.; Yang, W.; Zhao, L.; Pei, F.; Fang, D.; Hu, Q. A critical review on the health promoting effects of mushrooms nutraceuticals. Food Sci. Hum. Wellness 2018, 7, 125-133. [CrossRef]

17. Tung, Y.T.; Pan, C.H.; Chien, Y.W.; Huang, H.Y. Edible mushrooms: Novel medicinal agents to combat metabolic syndrome and associated diseases. Curr. Pharm. Des. 2020, 26, 4970-4981. [CrossRef] [PubMed]

18. Yang, S.; Yan, J.; Yang, L.; Meng, Y.; Wang, N.; He, C.; Fan, Y.; Zhou, Y. Alkali-soluble polysaccharides from mushroom fruiting bodies improve insulin resistance. Int. J. Biol. Macromol. 2019, 126, 466-474. [CrossRef]

19. Dasgupta, A.; Acharya, K. Mushrooms: An emerging resource for therapeutic terpenoids. 3 Biotech 2019, 9, 369. [CrossRef]

20. Kharroubi, A.T.; Darwish, H.M. Diabetes mellitus: The epidemic of the century. World J. Diabetes 2015, 6, 850-867. [CrossRef]

21. Gabir, M.M.; Hanson, R.L.; Dabelea, D.; Imperatore, G.; Roumain, J.; Bennett, P.H.; Knowler, W.C. The 1997 American Diabetes Association and 1999 World Health Organization criteria for hyperglycemia in the diagnosis and prediction of diabetes. Diabetes Care 2000, 23, 1108-1112. [CrossRef] 
22. Alam, F.; Islam, M.A.; Mohamed, M.; Ahmad, I.; Kamal, M.A.; Donnelly, R.; Idris, I.; Gan, S.H. Efficacy and safety of pioglitazone monotherapy in type 2 diabetes mellitus: A systematic review and meta-analysis of randomised controlled trials. Sci. Rep. 2019, 9, 5389. [CrossRef]

23. Vitak, T.; Yurkiv, B.; Wasser, S.; Nevo, E.; Sybirna, N. Effect of medicinal mushrooms on blood cells under conditions of diabetes mellitus. World J. Diabetes 2017, 8, 187-201. [CrossRef] [PubMed]

24. Misra, A.; Ramchandran, A.; Jayawardena, R.; Shrivastava, U.; Snehalatha, C. Diabetes in South Asians. Diabet. Med. 2014, 31, 1153-1162. [CrossRef]

25. Kosiborod, M.; Gomes, M.B.; Nicolucci, A.; Pocock, S.; Rathmann, W.; Shestakova, M.V.; Watada, H.; Shimomura, I.; Chen, H.; Cid-Ruzafa, J.; et al. Vascular complications in patients with type 2 diabetes: Prevalence and associated factors in 38 countries (the DISCOVER study program). Cardiovasc. Diabetol. 2018, 17, 150. [CrossRef] [PubMed]

26. Ndisang, J.F.; Vannacci, A.; Rastogi, S. Insulin resistance, type 1 and type 2 diabetes, and related complications 2017. J. Diabetes Res. 2017, 2017, 1478294. [CrossRef] [PubMed]

27. Ndisang, J.F.; Rastogi, S.; Vannacci, A. Insulin resistance, type 1 and type 2 diabetes, and related complications 2015. J. Diabetes Res. 2015, 2015, 234135. [CrossRef]

28. Taylor, R. Insulin resistance and type 2 diabetes. Diabetes 2012, 61, 778-779. [CrossRef] [PubMed]

29. Duvnjak, L.; Duvnjak, M. The metabolic syndrome-an ongoing story. J. Physiol. Pharmacol. Off. J. Pol. Physiol. Soc. 2009, 60 (Suppl. 7), 19-24.

30. Ndisang, J.F.; Rastogi, S.; Vannacci, A. Insulin resistance, type 1 and type 2 diabetes, and related complications: Current status and future perspective. J. Diabetes Res. 2014, 2014, 276475. [CrossRef]

31. Montoya, L.; Herrera, M.; Bandala, V.M.; Ramos, A. Two new species and a new record of yellow Cantharellus from tropical Quercus forests in eastern Mexico with the proposal of a new name for the replacement of Craterellus confluens. MycoKeys 2021, 80, 91. [CrossRef]

32. Hermawan, R.; Putra, I. Calvatia rugosa: Epigeous Puffball mushroom reported from West Java. Sci. Educ. Appl. J. 2021, 3, 1. [CrossRef]

33. Nowakowski, P.; Naliwajko, S.K.; Markiewicz-Żukowska, R.; Borawska, M.H.; Socha, K. The two faces of Coprinus comatusfunctional properties and potential hazards. Phytother. Res. 2020, 34, 2932-2944. [CrossRef] [PubMed]

34. Starzycki, M.; Paukszta, D.; Starzycka, E. Vitro growth of oyster mushroom (pleurotus ostreatus) mycelium on composites filled with rapeseed. Phytopathologia 2014, 65, 33-37.

35. Frank, J.; Siegel, N.; Schwarz, C.; Araki, B.; Vellinga, E. Xerocomellus (Boletaceae) in western North America. Fungal Syst. Evol. 2020, 6, 265-288. [CrossRef] [PubMed]

36. Elkhateeb, W.; Ezzat el ghwas, D.; Gundoju, N.; Tiruveedhula, S.; Akram, M.; Daba, G. Chicken of the woods Laetiporus Sulphureus and Schizophyllum Commune treasure of medicinal mushrooms. J. Microbiol. Biotechnol. 2021, 6, 1-7. [CrossRef]

37. Dissanayake, A.A.; Zhang, C.R.; Mills, G.L.; Nair, M.G. Cultivated maitake mushroom demonstrated functional food quality as determined by in vitro bioassays. J. Funct. Foods 2018, 44, 79-85. [CrossRef]

38. Ekowati, N.; Yuniati, N.I.; Hernayanti, H.; Ratnaningtyas, N.I. Antidiabetic potentials of button mushroom (Agaricus bisporus) on alloxan-induced diabetic rats. Biosaintifika J. Biol. Biol. Educ. 2018, 10, 655-662. [CrossRef]

39. Halama, M.; Pech, P.; Shiryaev, A.G. Contribution to the knowledge of Ramariopsis subarctica (Clavariaceae, Basidiomycota). Pol. Bot. J. 2017, 62, 123-133. [CrossRef]

40. Masaphy, S.; Zabari, L.; Goldberg, D.; Jander-Shagug, G. The complexity of Morchella systematics: A case of the yellow morel from Israel. Fungi 2010, 3, 14-18.

41. Wu, D.; Yang, S.; Tang, C.; Liu, Y.; Li, Q.; Zhang, H.; Cui, F.; Yang, Y. Structural properties and macrophage activation of cell wall polysaccharides from the fruiting bodies of Hericium erinaceus. Polymers 2018, 10, 850. [CrossRef]

42. Bao, D.; Gong, M.; Zheng, H.; Chen, M.; Zhang, L.; Wang, H.; Jiang, J.; Wu, L.; Zhu, Y.; Zhu, G.; et al. Sequencing and comparative analysis of the straw mushroom (Volvariella volvacea) genome. PLoS ONE 2013, 8, e58294. [CrossRef]

43. Liang, C.; Tian, D.; Liu, Y.; Li, H.; Zhu, J.; Li, M.; Xin, M.; Xia, J. Review of the molecular mechanisms of Ganoderma lucidum triterpenoids: Ganoderic acids A, C2, D, F, DM, X and Y. Eur. J. Med. Chem. 2019, 174, 130-141. [CrossRef] [PubMed]

44. Lin, C.P.; Tsai, S.-Y. Differences in the moisture capacity and thermal stability of Tremella fuciformis polysaccharides obtained by various drying processes. Molecules 2019, 24, 2856. [CrossRef] [PubMed]

45. Senthilarasu, G. The lentinoid fungi (Lentinus and Panus) from Western Ghats, India. IMA Fungus 2015, 6, 119-128. [CrossRef] [PubMed]

46. Chakraborty, B.; Chakraborty, U.; Barman, S.; Roy, S. Effect of different substrates and casing materials on growth and yield of Calocybe indica (P\&C) in North Bengal, India. J. Appl. Nat. Sci. 2016, 8, 683-690.

47. Karun, N.; Sharma, B.; Sridhar, K. Biodiversity of macrofungi in Yenepoya Campus, Southwest India. Microb. Biosyst. 2018, 3 , 1-11. [CrossRef]

48. Adhikari, M.K.; Watanabe, K.; Parajuli, G. A new variety of Pholiota microspora (Agaricales) from Nepal. Biodiversitas J. Biol. Divers. 2014, 15, 101-103. [CrossRef]

49. Hu, Y.-N.; Sung, T.-J.; Chou, C.-H.; Liu, K.-L.; Hsieh, L.-P.; Hsieh, C.-W. Characterization and antioxidant activities of yellow Strain Flammulina velutipes (Jinhua Mushroom) polysaccharides and their effects on ROS content in L929 cell. Antioxidants 2019, 8, 298. [CrossRef] 
50. Chicatto, J.; Castamann, V.; Helm, C.; Tavares, L. Optimization of the production process of enzymatic activity of Lentinula edodes (Berk.) pegler in holocelulases. Nat. Resour. 2014, 5, 241-255. [CrossRef]

51. Shah, S.R.; Ukaegbu, C.I.; Hamid, H.A.; Alara, O.R. Evaluation of antioxidant and antibacterial activities of the stems of Flammulina velutipes and Hypsizygus tessellatus (white and brown var.) extracted with different solvents. J. Food Meas. Charact. 2018, 12, 1947-1961. [CrossRef]

52. Nagalakshmi, M.; Krishnakumari, S.; Kathiravan, S. Comparitive study of various substrate supplements in the growth and yield of Agrocybe aegerita, black poplar mushroom. World J. Pharm. Res. 2014, 3, 487-496.

53. Rahmad, N.; Al-Obaidi, J.; Mohd Nor Rashid, N.; Zean, N.; Yuswan, M.H.; Shaharuddin, N.; Mohd Jamil, N.A.; Mohd Saleh, N. Comparative proteomic analysis of different developmental stages of the edible mushroom Termitomyces heimii. Biol. Res. 2014, 47, 30. [CrossRef] [PubMed]

54. Ogbole, O.O.; Nkumah, A.O.; Linus, A.U.; Falade, M.O. Molecular identification, in vivo and in vitro activities of Calvatia gigantea (macro-fungus) as an antidiabetic agent. Mycology 2019, 10, 166-173. [CrossRef] [PubMed]

55. Gao, Z.; Kong, D.; Cai, W.; Zhang, J.; Jia, L. Characterization and anti-diabetic nephropathic ability of mycelium polysaccharides from Coprinus comatus. Carbohydr. Polym. 2021, 251, 117081. [CrossRef] [PubMed]

56. Asrafuzzaman, M.; Rahman, M.; Mandal, M.; Marjuque, M.; Bhowmik, D.; Begum, R.; Hassan, M.Z.; Faruque, M. Oyster mushroom functions as an anti-hyperglycaemic through phosphorylation of AMPK and increased expression of GLUT4 in type 2 diabetic model rats. J. Taibah Univ. Med. Sci. 2018, 13, 465-471. [CrossRef]

57. Ali Sangi, S.; Bawadekji, A.; Al Ali, M. Comparative effects of metformin, Pleurotus ostreatus, Nigella sativa, and Zingiber officinale on the streptozotocin-induced diabetes mellitus in rats. Pharmacogn. Mag. 2018, 14, 268-273. [CrossRef]

58. Xiao, Y.; Chen, L.; Fan, Y.; Yan, P.; Li, S.; Zhou, X. The effect of boletus polysaccharides on diabetic hepatopathy in rats. Chem.-Biol. Interact. 2019, 308, 61-69. [CrossRef]

59. Xiao, C.; Jiao, C.; Xie, Y.; Ye, L.; Li, Q.; Wu, Q. Grifola frondosa GF5000 improves insulin resistance by modulation the composition of gut microbiota in diabetic rats. J. Funct. Foods 2021, 77, 104313. [CrossRef]

60. Patel, D.K.; Dutta, S.D.; Ganguly, K.; Cho, S.J.; Lim, K.T. Mushroom-derived bioactive molecules as immunotherapeutic agents: A review. Molecules 2021, 26, 1359. [CrossRef]

61. Blumfield, M.; Abbott, K.; Duve, E.; Cassettari, T.; Marshall, S.; Fayet-Moore, F. Examining the health effects and bioactive components in Agaricus bisporus mushrooms: A scoping review. J. Nutr. Biochem. 2020, 84, 108453. [CrossRef]

62. Wu, H.; Chen, J.; Li, J.; Liu, Y.; Park, H.; Yang, L. Recent advances on bioactive ingredients of Morchella esculenta. Appl. Biochem. Biotechnol. 2021, 193, 4197-4213. [CrossRef]

63. Zhang, C.; Li, J.; Hu, C.; Wang, J.; Zhang, J.; Ren, Z.; Song, X.; Jia, L. Antihyperglycaemic and organic protective effects on pancreas, liver and kidney by polysaccharides from Hericium erinaceus SG-02 in streptozotocin-induced diabetic mice. Sci. Rep. 2017, 7, 10847. [CrossRef] [PubMed]

64. Thongbai, B.; Rapior, S.; Hyde, K.D.; Wittstein, K.; Stadler, M. Hericium erinaceus, an amazing medicinal mushroom. Mycol. Prog. 2015, 14, 91. [CrossRef]

65. Huang, C.-H.; Lin, W.-K.; Chang, S.H.; Tsai, G.-J. Evaluation of the hypoglycaemic and antioxidant effects of submerged Ganoderma lucidum cultures in type 2 diabetic rats. Mycology 2021, 12, 82-93. [CrossRef] [PubMed]

66. Zeb, M.; Lee, C.H. Medicinal properties and bioactive compounds from wild mushrooms native to North America. Molecules 2021, 26, 251. [CrossRef]

67. Wang, Y.; Zhang, H. Advances in the extraction, purification, structural-property relationships and bioactive molecular mechanism of Flammulina velutipes polysaccharides: A review. Int. J. Biol. Macromol. 2021, 167, 528-538. [CrossRef]

68. Song, X.; Fu, H.; Chen, W. Effects of Flammulina velutipes polysaccharides on quality improvement of fermented milk and antihyperlipidemic on streptozotocin-induced mice. J. Funct. Foods 2021, 87, 104834. [CrossRef]

69. Rivera, O.A.; Albarracín, W.; Lares, M. Bioactive components of shiitake (Lentinula edodes Berk. Pegler) and its impact on health Arch. Venez. De Farmacol. Y Ter. 2017, 36, 67-71.

70. Laurino, L.F.; Viroel, F.J.M.; Caetano, E.; Spim, S.; Pickler, T.B.; Rosa-Castro, R.M.; Vasconcelos, E.A.; Jozala, A.F.; Hataka, A.; Grotto, D.; et al. Lentinus edodes exposure before and after fetus implantation: Materno-fetal development in rats with gestational diabetes mellitus. Nutrients 2019, 11, 2720. [CrossRef]

71. Ugbogu, E.A.; Akubugwo, E.; Ude, V.; Okezie, E.; Nduka, O.; Ibeh, C.; Onyero, O. Safety evaluation of aqueous extract of Termitomyces robustus (Agaricomycetes) in Wistar Rats. Int. J. Med. Mushrooms 2018, 21, 193-203. [CrossRef]

72. Wondmkun, Y.T. Obesity, insulin resistance, and type 2 diabetes: Associations and therapeutic implications. Diabetes Metab. Syndr. Obes. 2020, 13, 3611-3616. [CrossRef]

73. Shyur, L.-F.; Varga, V.; Chen, C.-M.; Mu, S.-C.; Chang, Y.-C.; Li, S.-C. Extract of white sweet potato tuber against TNF- $\alpha$-induced insulin resistance by activating the PI3K/Akt pathway in C2C12 myotubes. Bot. Stud. 2021, 62, 7. [CrossRef] [PubMed]

74. Nolan, C.J.; Prentki, M. Insulin resistance and insulin hypersecretion in the metabolic syndrome and type 2 diabetes: Time for a conceptual framework shift. Diabetes Vasc. Dis. Res. 2019, 16, 118-127. [CrossRef] [PubMed]

75. Junttila, M.J.; Kiviniemi, A.M.; Lepojärvi, E.S.; Tulppo, M.; Piira, O.-P.; Kenttä, T.; Perkiömäki, J.S.; Ukkola, O.H.; Myerburg, R.J.; Huikuri, H.V. Type 2 diabetes and coronary artery disease: Preserved ejection fraction and sudden cardiac death. Heart Rhythm. 2018, 15, 1450-1456. [CrossRef]

76. Czech, M.P. Insulin action and resistance in obesity and type 2 diabetes. Nat. Med. 2017, 23, 804-814. [CrossRef] [PubMed] 
77. Shulman, G.I. Ectopic fat in insulin resistance, dyslipidemia, and cardiometabolic disease. N. Engl. J. Med. 2014, 371, 1131-1141. [CrossRef] [PubMed]

78. Aramabašić Jovanović, J.; Mihailović, M.; Uskoković, A.; Grdović, N.; Dinić, S.; Vidaković, M. The effects of major mushroom bioactive compounds on mechanisms that control blood glucose level. J. Fungi 2021, 7, 58. [CrossRef] [PubMed]

79. Grondin, J.M.; Tamura, K.; Déjean, G.; Abbott, D.W.; Brumer, H. Polysaccharide utilization loci: Fueling microbial communities. J. Bacteriol. 2017, 199, e00860-16. [CrossRef]

80. Dubey, S.K.; Chaturvedi, V.K.; Mishra, D.; Bajpeyee, A.; Tiwari, A.; Singh, M.P. Role of edible mushroom as a potent therapeutics for the diabetes and obesity. 3 Biotech 2019, 9, 450. [CrossRef]

81. Kou, L.; Du, M.; Liu, P.; Zhang, B.; Zhang, Y.; Yang, P.; Shang, M.; Wang, X. Anti-diabetic and anti-nephritic activities of Grifola frondosa mycelium polysaccharides in diet-streptozotocin-induced diabetic rats via modulation on oxidative stress. Appl. Biochem. Biotechnol. 2019, 187, 310-322. [CrossRef]

82. Ratnaningtyas, N.I.; Hernayanti, H.; Andarwanti, S.; Ekowati, N.; Purwanti, E.S.; Sukmawati, D. Effects of Ganoderma lucidum extract on diabetic rats. Biosaintifika J. Biol. Biol. Educ. 2018, 10, 6. [CrossRef]

83. Lin, X.; Brennan-Speranza, T.C.; Levinger, I.; Yeap, B.B. Undercarboxylated osteocalcin: Experimental and human evidence for a role in glucose homeostasis and muscle regulation of insulin sensitivity. Nutrients 2018, 10, 847. [CrossRef] [PubMed]

84. Zhang, L.; Hu, Y.; Duan, X.; Tang, T.; Shen, Y.; Hu, B.; Liu, A.; Chen, H.; Li, C.; Liu, Y. Characterization and antioxidant activities of polysaccharides from thirteen boletus mushrooms. Int. J. Biol. Macromol. 2018, 113, 1-7. [CrossRef] [PubMed]

85. Khursheed, R.; Singh, S.K.; Wadhwa, S.; Gulati, M.; Awasthi, A. Therapeutic potential of mushrooms in diabetes mellitus: Role of polysaccharides. Int. J. Biol. Macromol. 2020, 164, 1194-1205. [CrossRef]

86. Panigrahy, S.; Bhatt, R.; Kumar, A. Targeting type II diabetes with plant terpenes: The new and promising antidiabetic therapeutics Biologia 2020, 76, 241-254. [CrossRef]

87. Kolundzic, M.; Grozdanić, N.; Stanojkovic, T.; Milenkovic, M.; Dinic, M.; Golić, N.; Kojic, M.; Kundaković, T. Antimicrobial and cytotoxic activities of the sulphur shelf medicinal mushroom laetiporus sulphureus (Agaricomycetes) from Serbia. Int. J. Med. Mushrooms 2016, 18, 469-476. [CrossRef]

88. Ma, X.; Yang, M.; He, Y.; Zhai, C.; Li, C. A review on the production, structure, bioactivities and applications of Tremella polysaccharides. Int. J. Immunopathol. Pharmacol. 2021, 35, 20587384211000541. [CrossRef]

89. Zhu, G.; Hayashi, M.; Shimomura, N.; Yamaguchi, T.; Aimi, T. Differential expression of three $\alpha$-amylase genes from the basidiomycetous fungus Pholiota microspora. Mycoscience 2017, 58, 188-191. [CrossRef]

90. Cardwell, G.; Bornman, J.F.; James, A.P.; Black, L.J. A review of mushrooms as a potential source of dietary vitamin D. Nutrients 2018, 10, 1498. [CrossRef]

91. Sung, C.-C.; Liao, M.-T.; Lu, K.-C.; Wu, C.-C. Role of vitamin D in insulin resistance. J. Biomed. Biotechnol. 2012, 2012, 634195 [CrossRef]

92. Szymczak-Pajor, I.; Drzewoski, J.; Śliwińska, A. The molecular mechanisms by which vitamin D prevents insulin resistance and associated disorders. Int. J. Mol. Sci. 2020, 21, 6644. [CrossRef]

93. Talaei, A.; Mohamadi, M.; Adgi, Z. The effect of vitamin D on insulin resistance in patients with type 2 diabetes. Diabetol. Metab. Syndr. 2013, 5, 8. [CrossRef]

94. Zakhary, C.M.; Rushdi, H.; Hamdan, J.A.; Youssef, K.N.; Khan, A.; Abdalla, M.A.; Khan, S. Protective role of vitamin D therapy in diabetes mellitus type II. Cureus 2021, 13, e17317. [CrossRef]

95. Al-Shoumer, K.A.; Al-Essa, T.M. Is there a relationship between vitamin D with insulin resistance and diabetes mellitus? World J. Diabetes 2015, 6, 1057-1064. [CrossRef] [PubMed]

96. Urbain, P.; Singler, F.; Ihorst, G.; Biesalski, H.K.; Bertz, H. Bioavailability of vitamin $\mathrm{D}_{2}$ from UV-B-irradiated button mushrooms in healthy adults deficient in serum 25-hydroxyvitamin D: A randomized controlled trial. Eur. J. Clin. Nutr. 2011, 65, 965-971. [CrossRef] [PubMed]

97. Wenclewska, S.; Szymczak-Pajor, I.; Drzewoski, J.; Bunk, M.; Śliwińska, A. Vitamin D supplementation reduces both oxidative DNA damage and insulin resistance in the elderly with metabolic disorders. Int. J. Mol. Sci. 2019, 20, 2891. [CrossRef] [PubMed]

98. Mutt, S.J.; Raza, G.S.; Mäkinen, M.J.; Keinänen-Kiukaanniemi, S.; Järvelin, M.R.; Herzig, K.H. Vitamin D deficiency induces insulin resistance and re-supplementation attenuates hepatic glucose output via the PI3K-AKT-FOXO1 mediated pathway. Mol. Nutr. Food Res. 2020, 64, e1900728. [CrossRef]

99. El Hajj, C.; Walrand, S.; Helou, M.; Yammine, K. Effect of vitamin D supplementation on inflammatory markers in non-obese Lebanese patients with type 2 diabetes: A randomized controlled trial. Nutrients 2020, 12, 2033. [CrossRef]

100. Cojic, M.; Kocic, R.; Klisic, A.; Kocic, G. The effects of vitamin D supplementation on metabolic and oxidative stress markers in patients with type 2 diabetes: A 6-month follow up randomized controlled study. Front. Endocrinol. 2021, 12, 610893. [CrossRef] 